\title{
The Influence of Water on the Properties of Polyester Laminates Made by Manual Air Extrusion
}

\author{
Vlatko MARUŠIĆ, Ivan SAMARDŽIĆ, Ivan OPAČAK, Dejan ŠAKIĆ
}

\begin{abstract}
The mechanical properties of polyester composites reinforced by various combinations of glass fibre types were investigated. The samples were tested before and after the operation of the wet media in the salt chamber. Cross sections were recorded to determine the presence of cavities. It was concluded that the properties of composites depended not only on the number and type of reinforcement but also much more on the portion of cavities. It is concluded that the intermediate surface with a smaller portion of the cavities contributes to the compositions to be firmer and stiffer, but also fragile. As a result, the negative influence of water increases with the increase of porosity.
\end{abstract}

Keywords: glass fibres; mechanical properties; polyester composites; porosity; water

\section{INTRODUCTION}

The advantage of composite materials over other types of materials is seen in the simple production of (and) very complicated forms, in lower price, less weight and in better resistance of such materials to aggressive media. Characteristics of allowed loads in service depend on mechanical properties of materials, i.e. on their tensile strength, on bending strength and toughness, as well as on the shear strength [1]. Glass fibres have defined mechanical properties, however, certain types and combination of reinforcements can affect their behaviour under specific service conditions [2]. Cavities occur while creating each composite, regardless of the process of production. One of the reasons for such occurrence are air bubbles that remain trapped in the material within the initial stage of production. Another reason is the release of easily evaporable products during the hardening phase of the composite at elevated temperatures [3]. Because of the weaker connection between the matrix and reinforcement, the increase in the portion of cavities has negative influence on the mechanical properties [4].

Samples of manually prepared plates were tested for the dependence of mechanical properties on the number, combination and arrangement of different types of glass fibres under the conditions of water action. The aim was to determine to what extent the combination and type of glass fibre knits could influence the mechanical properties of polyester laminates, by paying attention to the influence of water media.

\section{CHARACTERISTICS OF PRODUCTION AND APPLICATION OF POLYESTER LAMINATES REINFORCED BY GLASS FIBRES}

According to the type of reinforcement, they are divided into mat, roving and combimat.

The mat usually consists of equally thick layer of fibres that are scattered on surface in all directions (unbound fibres).

Laminate made with mat has equal properties in all directions. Roving is a simple cropped fabric that has the base and the stem most often $\left(0^{\circ}: 90^{\circ}\right)$ and it usually has equally thick strands. It has better properties in two distinct directions, and worse for all cross-directions.

Combimat is a combination of fiberglass (roving) and chopped glass fibres (mat). The layers are joined by sewing with polyester thread into one single layer. The layer of chopped glass fibres (mat) is applied to achieve better interlaminar strength, and the purpose of joining the two layers is obtaining faster service and more accurate maintenance of the defined reinforcement mass. The outer layer (gel coat) serves to protect and decorate. The inner layer (top coat) protects the laminate from inside and it is of similar formulation as the outer layer. Since the most laminate strength comes from reinforcement, this built-in reinforcement mass is important for the final product appreciation. Therefore, in addition to defining the type of weave, the surface reinforcement mass is also mandatory to be stated. Standard surface masses are 225, 300, 450, $600 \mathrm{~g} / \mathrm{m}^{2}$. Fig. 1 presents a characteristic cross-section of a glass fibre reinforced composite made by manual air extrusion by using a roller.

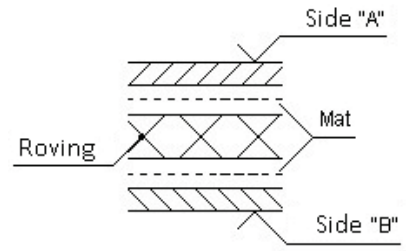

a)

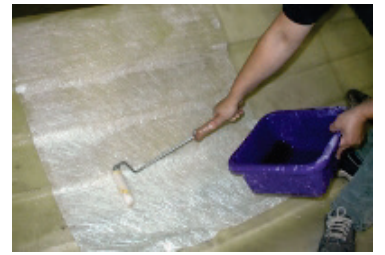

b)
Figure 1 Composite reinforced by glass fibres a) characteristic cross-section; b) manual air extrusion by roller

There are two most common processes of making products of polyester laminates. One is manual procedure where the air bubbles are extruded by hand with a roller.

The other is the Resin Transfer Molding - RTM procedure, where the air bubbles are "extracted" by vacuum (injection pressing in vacuum). Manual procedure is usually used in individual, and the RTM is used in serial production. The advantage of manual air bubble extrusion is found in its simplicity, minimum costs, work at a room temperature and small work space required. The disadvantages are styrene vaporization, great portion of labour contained in the product price and there is only one side "smooth". Because of its specific properties, glass fibre reinforced composite materials are used in 
shipbuilding [5], in transport vehicle industry [6], in agriculture, chemical and process industries, and in leisure equipment production [7]. Characteristic examples of such application are shown in Fig. 2.

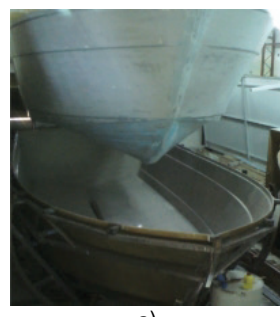

a)

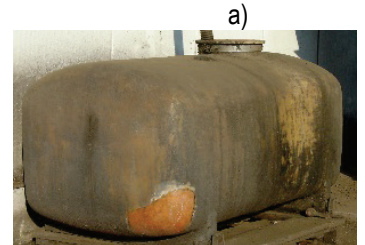

c)

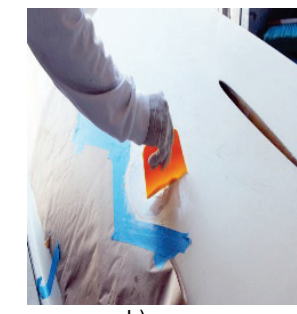

b)

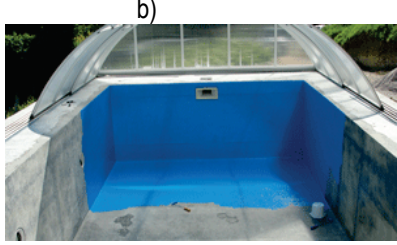

d)
Figure 2 Characteristic examples of composite materials applications a) vessels [5]; b) car parts [6]; c) containers for the processing industry; d) pools [7]

\section{EXPERIMENT PLAN}

For the purpose of carrying out the research into influence of water on properties of polyester laminates reinforced by glass fibre within manual air extrusion process, the authors prepared 5 plates in different reinforcement combinations.

Table 1 Composition of tested plates

\begin{tabular}{|c|c|c|c|c|}
\hline \multicolumn{5}{|c|}{ Plate label } \\
\hline 1 & 2 & 3 & 4 & 5 \\
\hline $\begin{array}{l}\text { Side "A"- } \\
\quad \text { resin } \\
+ \text { calcite }\end{array}$ & $\begin{array}{c}\text { Side } \\
\text { "A"- } \\
\text { resin } \\
+ \text { calcite }\end{array}$ & $\begin{array}{l}\text { Side "A"- } \\
\quad \text { resin } \\
+ \text { calcite }\end{array}$ & $\begin{array}{l}\text { Side "A"- } \\
\text { resin } \\
+ \text { calcite }\end{array}$ & $\begin{array}{l}\text { Side "A"- } \\
\text { resin } \\
+ \text { calcite }\end{array}$ \\
\hline $\begin{array}{c}2 \text { layers of } \\
\text { mat } \\
\left(450 \mathrm{~g} / \mathrm{m}^{2}\right)\end{array}$ & $\begin{array}{c}2 \text { layers } \\
\text { of mat } \\
(300 \\
\left.\mathrm{g} / \mathrm{m}^{2}\right)\end{array}$ & $\begin{array}{c}1 \text { layer } \\
\text { of mat } \\
\left(450 \mathrm{~g} / \mathrm{m}^{2}\right)\end{array}$ & $\begin{array}{c}3 \text { layers of } \\
\text { mat } \\
\left(450 \mathrm{~g} / \mathrm{m}^{2}\right)\end{array}$ & $\begin{array}{c}2 \text { layers of } \\
\text { mat } \\
\left(300 \mathrm{~g} / \mathrm{m}^{2}\right)\end{array}$ \\
\hline $\begin{array}{c}1 \text { layer } \\
\text { of fabric } \\
\left(300 \mathrm{~g} / \mathrm{m}^{2}\right)\end{array}$ & "combimat" & $\begin{array}{l}2 \text { layers of } \\
\text { fabric } \\
\left(300 \mathrm{~g} / \mathrm{m}^{2}\right)\end{array}$ & $\begin{array}{c}2 \text { layers of } \\
\text { mat } \\
\left(450 \mathrm{~g} / \mathrm{m}^{2}\right)\end{array}$ & $\begin{array}{l}2 \text { layers of } \\
\text { fibers } \\
\left(300 \mathrm{~g} / \mathrm{m}^{2}\right)\end{array}$ \\
\hline $\begin{array}{c}2 \text { layers of } \\
\text { mat } \\
\left(450 \mathrm{~g} / \mathrm{m}^{2}\right)\end{array}$ & $\begin{array}{c}1 \text { layer } \\
\text { of mat } \\
\left(450 \mathrm{~g} / \mathrm{m}^{2}\right)\end{array}$ & $\begin{array}{c}2 \text { layers of } \\
\text { mat } \\
\left(450 \mathrm{~g} / \mathrm{m}^{2}\right)\end{array}$ & $\begin{array}{l}\text { Side "B"- } \\
\text { gelcoat }\end{array}$ & $\begin{array}{c}1 \text { layer of } \\
\text { mat } \\
\left(450 \mathrm{~g} / \mathrm{m}^{2}\right)\end{array}$ \\
\hline $\begin{array}{l}\text { Side "B"- } \\
\text { gelcoat }\end{array}$ & $\begin{array}{c}\text { Side } \\
\text { "B"-gelcoat }\end{array}$ & $\begin{array}{l}\text { Side "B"- } \\
\text { gelcoat }\end{array}$ & - & $\begin{array}{l}\text { Side "B"- } \\
\text { gelcoat }\end{array}$ \\
\hline
\end{tabular}

Table 2 Experiment plan

\begin{tabular}{|c|c|c|c|c|c|c|}
\hline \multirow{2}{*}{$\begin{array}{c}\text { Ord. } \\
\text { No. }\end{array}$} & Standard & \multicolumn{3}{|c|}{ Plate label and number of tested samples } \\
\cline { 3 - 7 } 1. & $\begin{array}{c}\text { Tensile } \\
\text { strength, } \\
\text { DIN53455 }\end{array}$ & $5 \times 2$ & $5 \times 2$ & $5 \times 2$ & $5 \times 2$ & $5 \times 2$ \\
\hline \multirow{2}{*}{2.} & $\begin{array}{c}\text { Tensile } \\
\text { modulus of } \\
\text { elasticity, } \\
\text { DIN53457 }\end{array}$ & $5 \times 2$ & $5 \times 2$ & $5 \times 2$ & $5 \times 2$ & $5 \times 2$ \\
\hline 3. & $\begin{array}{c}\text { Interlayer } \\
\text { strength, } \\
\text { BS2782 }\end{array}$ & $(5+5) \times 2$ & $(5+5) \times 2$ & $(5+5) \times 2$ & $(5+5) \times 2$ & $(5+5) \times 2$ \\
\hline 4. & $\begin{array}{c}\text { Bending } \\
\text { strength, } \\
\text { DIN53452 }\end{array}$ & $(5+5) \times 2$ & $(5+5) \times 2$ & $(5+5) \times 2$ & $(5+5) \times 2$ & $(5+5) \times 2$ \\
\hline 5. & $\begin{array}{c}\text { Toughness, } \\
\text { DIN53453 }\end{array}$ & $(5+5) \times 2$ & $(5+5) \times 2$ & $(5+5) \times 2$ & $(5+5) \times 2$ & $(5+5) \times 2$ \\
\hline
\end{tabular}

Composition and thickness of plates are overviewed in Tab. 1. Influence of water was tested in a salt chamber. The media properties were as follows:

- $\quad 5 \%$ solution $\mathrm{NaCl}$;

- $\quad$ temperature of the media $40{ }^{\circ} \mathrm{C}$;

- duration of testing 15 days $\times 24 \mathrm{~h}$.

The number of plates used in the experiment is presented in the Tab. 2. There were 5 samples prepared for testing without prior action of the medium and 5 samples for testing after the medium action. All other experiments were performed on 20 samples, of which 5 for the side "A" and 5 for the side "B", 5 for testing without media and 5 for testing after the action of the media.

\section{RESULTS OF TESTING}

Samples were tested according to the experiment plan and the cross-section structure was recorded. Prior to that, plates were measured for their thickness and portion of inorganic substances was determined according to DIN 52330, Tab. 3. The portions of reinforcement mass in the laminate depend on the type of reinforcement, 1 layer of mat, 2 layers of mat, roving etc. [8]. Actual portions are obtained only after "hardening" and then burning all of samples.

Table 3 Thickness of plates and portion of inorganic substances

\begin{tabular}{|c|c|c|}
\hline $\begin{array}{c}\text { Ordinal No. } \\
\text { of plate }\end{array}$ & $\begin{array}{c}\text { Thickness of plates, } \\
\text { mean value / mm }\end{array}$ & $\begin{array}{c}\text { Portion of inorganic } \\
\text { substances / \% }\end{array}$ \\
\hline 1 & 4,1 & 44,76 \\
\hline 2 & 4,2 & 42,06 \\
\hline 3 & 3,9 & 47,85 \\
\hline 4 & 4,2 & 51,49 \\
\hline 5 & 4,0 & 44,79 \\
\hline
\end{tabular}

Table 4 Arithmetic mean of tensile strength, bending strength, tensile modulus of elasticity and toughness

\begin{tabular}{|c|c|c|c|}
\hline $\begin{array}{l}\text { Ordinal No. } \\
\text { of plate }\end{array}$ & Tensile strength / $\mathrm{MPa}$ & \multicolumn{2}{|c|}{$\begin{array}{c}\text { Tensile modulus of elasticity / } \\
\mathrm{MPa}\end{array}$} \\
\hline \multirow{2}{*}{1} & 117,4 & \multicolumn{2}{|c|}{12073} \\
\hline & 101,6 & \multicolumn{2}{|c|}{11820} \\
\hline \multirow{2}{*}{2} & 105,9 & \multicolumn{2}{|c|}{10916} \\
\hline & 97,7 & \multicolumn{2}{|c|}{10782} \\
\hline \multirow{2}{*}{3} & 141,5 & \multicolumn{2}{|c|}{12791} \\
\hline & 134,3 & \multicolumn{2}{|c|}{12700} \\
\hline \multirow{2}{*}{4} & 106,1 & \multirow{2}{*}{\multicolumn{2}{|c|}{$\begin{array}{l}8734 \\
8490\end{array}$}} \\
\hline & 87,4 & & \\
\hline \multirow{2}{*}{5} & 130,7 & \\
\hline & 111,6 & \multicolumn{2}{|c|}{9911} \\
\hline \multicolumn{2}{|c|}{ Bending strength / MPa } & \multicolumn{2}{|c|}{ Toughness $/ \mathrm{kJ} / \mathrm{m}^{2}$} \\
\hline Side "A" & Side "B" & Side "A" & Side "B" \\
\hline 251,1 & 239,5 & 76 & 92 \\
\hline 211,6 & 180,8 & 68 & 81 \\
\hline 202,7 & 233,5 & 87 & 88 \\
\hline 187,5 & 209,8 & 82 & 81 \\
\hline 247,1 & 291,0 & 77 & 115 \\
\hline 235,7 & 277,9 & 74 & 105 \\
\hline 157,3 & 212,0 & 71 & 75 \\
\hline 120,3 & 185,3 & 64 & 66 \\
\hline 209,0 & 175,2 & 77 & 89 \\
\hline 191,2 & 157,0 & 68 & 74 \\
\hline
\end{tabular}

\subsection{Mechanical Properties of Plates}

After completed testing, values of the arithmetic mean of tensile strength, tensile modulus of elasticity, interlayer strength and toughness were defined. The results are overviewed in Tab. 4 and Tab. 5. The data in the numerator 
refer to results without exposure to the medium, and in the denominator, the results are obtained after exposure to medium action in the salt chamber.

\begin{tabular}{|} 
Table 5 Arithmetic mean of interlayer strength \\
\begin{tabular}{|c|c|}
\hline \multicolumn{2}{|c|}{ Interlayer strength / MPa } \\
\hline Side "A" & Side "B" \\
\hline 23,7 & 24,5 \\
18,9 & 19,0 \\
\hline 16,8 & 19,8 \\
12,5 & 13,4 \\
\hline 18,7 & 21,8 \\
16,5 & 18,9 \\
\hline 24,9 & 25,1 \\
19,4 & 18,2 \\
\hline 19,3 & 22,8 \\
16,1 & 19,2 \\
\hline
\end{tabular}
\end{tabular}

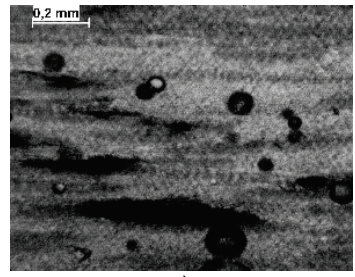

a)

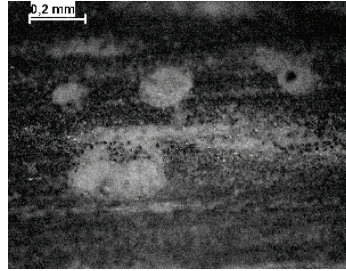

b)

Figure 3 Sample 1

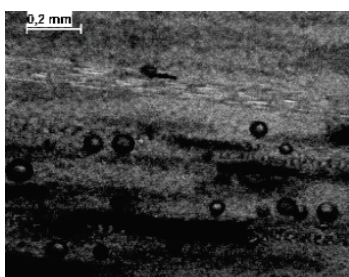

a)

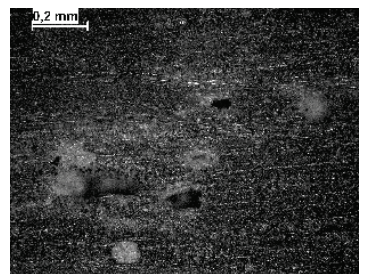

b)

Figure 4 Sample 2

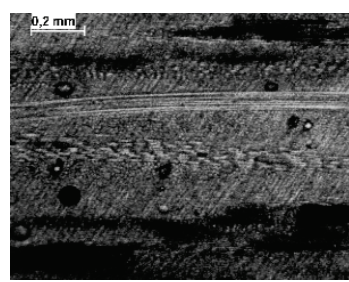

a)

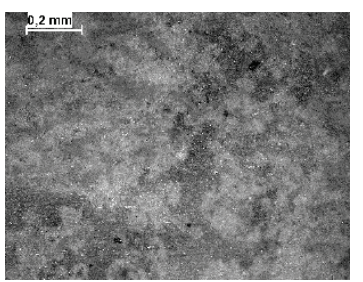

b)

Figure 5 Sample 3

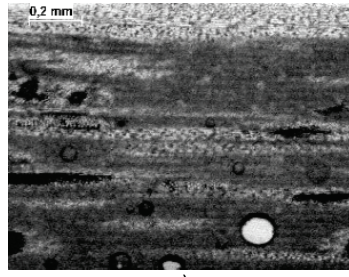

a)

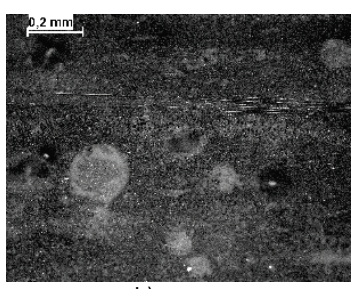

b)

Figure 6 Sample 4

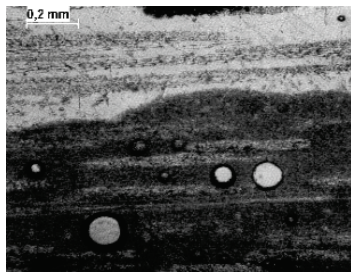

a)

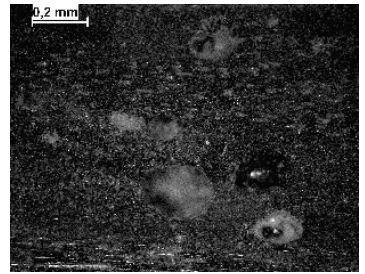

b)
Figure 7 Sample 5

\subsection{Structure of the Plate Cross-Sections}

The structure of characteristic cross-sections of each plate was recorded. The structure was observed by means of an optical microscope with polarized light.

Characteristic structures are presented in Figs. 3, 4, 5 , 6 and 7, a) without medium action, and b) after medium action.

\section{ANALYSIS OF RESULTS}

The average high ranking of plate 3 occurred most likely because of homogeneity of the structure, as well as most of the fabric layers (two layers) in the plate centre.

The influence of medium action was not present in great extent, and the measured values were lower than $10 \%$. Average ranking of the plate 5 is explained by reinforcement with two layers of fabric at the centre, with a moderate cavity content perpendicular to the crosssection. The decrease in mechanical properties due to the medium action is around $15 \%$. The differences in ranking of plates 1 and 4 (which also have two layers of fabric in the centre) are a consequence of significant portion of cavities. The media have strong negative effect on their properties, which are lowered by $20 \div 25 \%$.

Slightly lower mechanical properties of plate 2 can be attributed to less layers of reinforced material. Moderate presence of porosity in the form of cavities is noticed in the cross-section structure of this plate. After medium action, mechanical properties are lowered by $12 \div 15 \%$.

\section{CONCLUSION}

By changing layers, types of reinforcement, their layout and thickness, composite materials are achieving better properties in an optimal way. In production by soaking, it is very important to extrude the air. The number of present cavities in the marginal plates has negative effect on the mechanical properties, and this effect is even increased when influenced by media. With a lower porosity content, decrease in mechanical properties is around $10 \%$. Along with the increase of porosity and cavities, the mechanical properties are reduced by $20 \%$ and more. Further research should analyse the possibility of using the Resin Transfer Molding to reduce the presence of air bubbles and to achieve more homogeneous structure. This should result in better mechanical properties, especially in smooth upper surface, because for some areas of application it is aesthetically important to have both sides smooth ("A" and "B"). While doing so, it shall be mentioned that the lowering of porosity portion could reduce the negative influence of water on the mechanical properties of a material.

\section{REFERENCES}

[1] Ramesh, M., Palanikumar, K., \& Reddy, K. H. (2013). Mechanical property evaluation of sisal-jute-glass fiber reinforced polyester composites. Composites Part B: Engineering, 48, 1-9.

https://doi.org/10.1016/j.compositesb.2012.12.004

[2] Rassmann, S., Paskaramoorthy, R., \& Reid, R. G. (2011). Effect of resin system on the mechanical properties and 
water absorption of kenaf fibre reinforced laminates. Materials \& Design, 32(3), 1399-1406. https://doi.org/10.1016/j.matdes.2010.09.006

[3] Španiček, Đ. \& Vancaš, A. (2007). Određivanje sadržaja šupljina polimernih kompozita različitim metodama. Zbornik 12. Savjetovanja o materijalima, tehnologijama, trenju i trošenju / Vela Luka, 339-344.

[4] Nunna, S.; Chandra, R.; Shrivastava, S.; Jalan, A. K. (2012). A review on mechanical behaviour of natural fiber based hybrid composites. Journal of Reinforced Plastics and Composites, 31(11), 759-769. https://doi.org/10.1177/0731684412444325

[5] Marin Boat. Galerija. http://www.marin-boat.hr/ (15.02.2017)

[6] Composites World. New products. http://www.compositesworld.com/products/new (20.08.2016)

[7] Kompozit Kemija. Proizvodi. http://kompozit-kemija.hr/ proizvodi (09.03.2017)

[8] Lacković, V.; Krolo, J.; Ožbolt, J. (2011). Čvrstoća polimernog laminata pri složenom opterećenju. Građevinar, 63(1), 25-34

\section{Contact information:}

Vlatko MARUŠIĆ, Prof. Dr.

Mechanical Engineering Faculty in Slavonski Brod,

University of Josip Juraj Strossmayer in Osijek,

Trg Ivane Brlić-Mažuranić 2,

35000 Slavonski Brod, Croatia

E-mail:vmarusic@sfsb.hr

Ivan SAMARDŽIĆ, Prof. Dr.

Mechanical Engineering Faculty in Slavonski Brod,

University of Josip Juraj Strossmayer in Osijek,

Trg Ivane Brlić-Mažuranić 2 ,

35000 Slavonski Brod, Croatia

E-mail: isamar@sfsb.hr

Ivan OPAČAK, mag. ing. mech.

Mechanical Engineering Faculty in Slavonski Brod,

University of Josip Juraj Strossmayer in Osijek,

Trg Ivane Brlić-Mažuranić 2

35000 Slavonski Brod, Croatia

E-mail: iopacak@sfsb.hr

Dejan ŠAKIĆ, bacc. ing. techn. inf. University Applied Science Zagreb,

Vrbik 8, 10000 Zagreb, Croatia

E-mail: dsakic@tvz.hr 